\title{
Analisis dan Implementasi Pendekatan Hybrid untuk Sistem Rekomendasi dengan Metode Knowledge Based Recommender System dan Collaborative Filtering
}

\author{
Sari Rahmawati ${ }^{\# 1}$, Dade Nurjanah ${ }^{\# 2}$, Rita Rismala ${ }^{\# 3}$ \\ \# Fakultas Informatika, Universitas Telkom \\ Bandung, Indonesia \\ ${ }^{1}$ sari.rahmawati11@gmail.com \\ 2 dadenurjanah@telkomuniversity.ac.id \\ ${ }^{3}$ ritaris@telkomuniversity.ac.id
}

\begin{abstract}
Searching for jobs online can be an obstacle both to the applicant and companies looking for employees. Today many applicants and companies prefer to use online recruitment sites rather than search by using a search engine. Recommender system have one of the advantages of recruitment website because the website save employee profile information and make recommendations in accordance with the data they get. In this study the authors implement hybrid recommender system by combining two methods that is knowledge-based recommender system that will recommend jobs based on user profiles and job qualifications and collaborative filtering method that will recommend job based on other user influence. The prediction results of the two methods will be combined based on social aperture that will be given. Based on the results of testing hybrid recommender system provides the best results for predicting the interaction and provide recommendations based on the results of RMSE and F1 score.
\end{abstract}

Keywords: recommender system, hybrid recommender system, knowledge based recommender system, collaborative filtering

\begin{abstract}
Abstrak
Mencari pekerjaan secara online dapat menjadi kendala tersendiri baik pada pelamar pekerjaan maupun pada perusahaan yang mencari karyawan. Saat ini banyak pelamar dan perusahaan lebih memilih menggunakan situs rekruitasi online dibandingkan mencari dengan menggunakan mesin pencari. Recommender system menjadi salah satu kelebihan dari website rekruitasi karena website menyimpan informasi profil pekerja lalu memberikan rekomendasi sesuai dengan data yang mereka dapatkan. Pada penelitian ini penulis membuat hybrid recommender system dengan menggabungkan dua teknik yaitu knowledge based recommender system yang akan merekomendasikan pekerjaan berdasarkan profil user, kualifikasi pekerjaan dan pengaruh dari user lain yang akan memberikan rekomendasi pekerjaan berdasarkan user lain yang memiliki kesamaan. Hasil prediksi dari 2 metode itu akan digabungkan berdasarkan social aperture yang diberikan. Berdasarkan hasil pengujian hybrid recommender system memberikan hasil terbaik untuk memprediksi interaksi dan memberikan rekomendasi berdasarkan hasil RMSE dan F1 score.
\end{abstract}

Kata Kunci: recommender system, hybrid recommender system, knowledge based recommender system, collaborative filtering 
Sari Rahmawati ET.AL.

\section{PEndahuluan}

$\mathbf{P}$ ADA era digital saat ini, mendapatkan informasi yang sesuai dengan minat pengguna menjadi suatu tantangan tersendiri. Semakin meningkatnya aliran data dan informasi menjadi masalah bagi pengguna saat ingin mencari item yang dibutuhkan. Adanya recommender system dapat menangani masalah saat pengguna menerima informasi berlebih. Recommender system mengumpulkan informasi dari berbagai pilihan pengguna kepada sekumpulan item seperti buku, film, atau pekerjaan [1]. Salah satu bukti nyata pengaruh recommender system adalah sistem iklan pekerjaan yang hanya mengandalkan browsing dan pencarian pada mesin pencari, kini telah dikalahkan oleh sistem rekruitasi online seperti careerBuilder.com and monster.com. Kedua layanan online tersebut mencoba untuk memberi layanan dalam jangka panjang dengan merekomendasikan pekerjaan kepada pengguna berdasarkan informasi profil yang disediakan oleh pengguna [2].

Pada penelitian ini, penulis menggunakan dataset dari website Xing untuk merekomendasikan pekerjaan pada pengguna. Xing adalah social network untuk bisnis yang digunakan oleh para pencari kerja dan perekrut untuk menemukan kandidat yang cocok pada pekerjaan yang ditawarkan [3]. Penulis menggabungkan metode knowledge based dan collaborative filtering agar pengguna dapat diberikan rekomendasi berdasarkan karakteristik pekerjaan dari preferensi pengguna, setelah itu diberikan rekomendasi dari social network menggunakan collaborative filtering. Rekomendasi hybrid menggabungkan dua metode ini dengan menggunakan social aperture sebagai parameter pengaruh prediksi pada knowledge based recommender system dan collaborative filtering [3]. Tujuan dari pelaksanaan penelitian ini adalah menganalisa pengaruh sistem rekomendasi hybrid berdasarkan hasil prediksi dan rekomendasi dibandingkan dengan metode collaborative filtering dan knowledge based saja.

\section{PENELITIAN TERKAIT}

\section{A. Recommender System}

Recommender system yang ada pada saat ini terdiri dari empat tipe yaitu collaborative filtering, content based recommender system, knowledge based recommender system dan hybrid recommender system [1]. Masing masing metode tersebut memiliki kelemahan dan kelebihan. Collaborative filtering dapat merekomendasikan pekerjaan berdasarkan kumpulan pengguna yang memiliki kesukaan yang sama dengan pengguna tersebut. Knowledge based recommender system memodelkan pengguna berdasarkan pada pengetahuan mengenai pengguna tersebut dan merekomendasikan pekerjaan jika pekerjaan tersebut sudah memenuhi kebutuhan pengguna. Namun kedua metode tersebut memiliki kelemahan yaitu pada knowledge based recommender system dapat terjadi kegagalan rekomendasi jika pengguna tidak memberi deskripsi yang jelas. Pada collaborative filtering masalah terjadi jika ada sparsity pada data sehingga jika suatu pekerjaan tidak pernah direkomendasikan oleh pengguna lain, pekerjaan tersebut akan jarang muncul pada rekomendasi.

\section{B. Collaborative Filtering}

Pada collaborative filtering, pengguna aktif akan memberikan rekomendasi kepada pengguna lain yang memiliki preferensi yang sama berdasarkan similarity dari tiap tiap pengguna. Proses collaborative filtering dilakukan dengan melihat persamaan rating pada pekerjaan dengan metode user to user. Similarity antara pengguna dapat dihitung berdasarkan dari rating yang diberikan pada oleh pengguna. Metode collaborative filtering juga sering disebut sebagai "people-to-people correlation" [1].

Proses pada collaborative filtering dimulai dengan menghitung similarity antar pengguna yang memiliki ketertarikan yang sama dengan menggunakan persamaan 1. Kemudian dihitung prediksi interaksi menggunakan persamaan 2 [1]. 
Keterangan:

$$
\mathrm{S}_{\mathrm{uj}}=\frac{\sum_{\mathrm{x} \in I_{u j}}\left(\mathrm{U}_{\mathrm{x}}-\overline{\mathrm{U}}\right)\left(\mathrm{J}_{\mathrm{x}}-\overline{\mathrm{J}}\right)}{\sqrt{\sum_{\mathrm{x} \in I_{u j}}\left(\mathrm{U}_{\mathrm{x}}-\overline{\mathrm{U}}\right)^{2} \sum_{\mathrm{x} \in I_{u j}}\left(\mathrm{~J}_{\mathrm{x}}-\overline{\mathrm{J}}\right)^{2}}}
$$

- $\mathrm{S}_{\mathrm{uj}}$ adalah similarity antara pengguna $\mathrm{u}$ dan pengguna $\mathrm{j}$

- $U_{x}$ adalah interaksi pengguna $u$ pada pekerjaan $\mathrm{x}$

- $\overline{\mathrm{U}}$ adalah rata rata interaksi dari pengguna $\mathrm{u}$

- $\mathrm{J}_{\mathrm{X}}$ adalah interaksi dari pengguna $\mathrm{j}$ pada pekerjaan $\mathrm{x}$

- J adalah rata rata interaksi dari pengguna $j$

Keterangan:

$$
\mathrm{U}_{\mathrm{x}}^{\prime}=\overline{\mathrm{U}}+\frac{\sum_{\mathrm{j} \in \text { Raters of } \mathrm{x}}\left(\mathrm{J}_{\mathrm{x}}-\overline{\mathrm{J}}\right) \mathrm{S}_{\mathrm{uj}}}{\sum_{\mathrm{j} \in \text { Raters of } \mathrm{x}}\left|\mathrm{S}_{\mathrm{uj}}\right|}
$$

- $\quad \mathrm{U}_{\mathrm{x}}^{\prime}$ adalah prediksi interaksi pengguna u pada pekerjaan $\mathrm{x}$

- $\quad \bar{U}$ adalah rata rata interaksi dari pengguna $\mathrm{u}$

- $\quad \mathrm{J}_{\mathrm{X}}$ adalah interaksi dari pengguna $\mathrm{j}$ pada pekerjaan $\mathrm{x}$

- $\quad \mathrm{S}_{\mathrm{uj}}$ adalah similarity antara pengguna $\mathrm{u}$ dan pengguna $\mathrm{j}$

\section{Knowledge Based Reommender System}

Knowledge based system merekomendasikan pekerjaan berdasarkan domain knowledge, tentang pengaruh fitur dari pekerjaan terhadap kebutuhan dan preferensi pribadi pengguna [1]. Pada kasus ini similarity score pada knowledge based system merepresentasikan kesamaan fitur antara pekerjaan yang berbeda. Nilai similarity antar individu bisa didapatkan dengan persamaan 3 [4]. Similarity direpresentasikan dengan reference matrix.

$$
\mathrm{S}_{\mathrm{ab}}=\sum_{\mathrm{i}=1}^{\# \mathrm{p}}\left(\frac{\operatorname{common}(\mathrm{a}, \mathrm{b}, \mathrm{P}[\mathrm{i}])}{\max (\operatorname{deg}(\mathrm{a}, \mathrm{P}[\mathrm{i}]), \operatorname{deg}(\mathrm{b}, \mathrm{P}[\mathrm{i}])))}\right) * \text { Weight }(\mathrm{P}[\mathrm{i}])
$$

Keterangan:

- P (properties) adalah vektor yang mengandung sejumlah atribut dan hubungan antar atribut pada reference class dalam formula tersebut digunakan untuk menghitung similarity

- $\quad \operatorname{deg}(\mathrm{a}, \mathrm{P})$ merepresentasikan jumlah instance yang terhubung dengan individual a melalui relasi $\mathrm{P}$

- $\quad \operatorname{common}(\mathrm{a}, \mathrm{b}, \mathrm{P})$ merepresentasikan jumlah instance sama yang terhubung dengan adan $\mathrm{b}$ melalui relasi dari property $\mathrm{P}$

- Weight(P) menandakan pentingnya suatu property pada relasi P dalam formula

Kemudian setelah didapatkan reference matrix, dilakukan proses inferensi pengguna untuk mendapatkan hubungan dari suatu pekerjaan terhadap preferensi dari pengguna yang ditujunya sesuai dengan relasi pada objek dan pengguna dengan menggunakan Algoritma 1 [4]. Hasilnya berupa recon vector, yaitu vektor yang merepresentasikan derajat minat pengguna terhadap pekerjaan target.

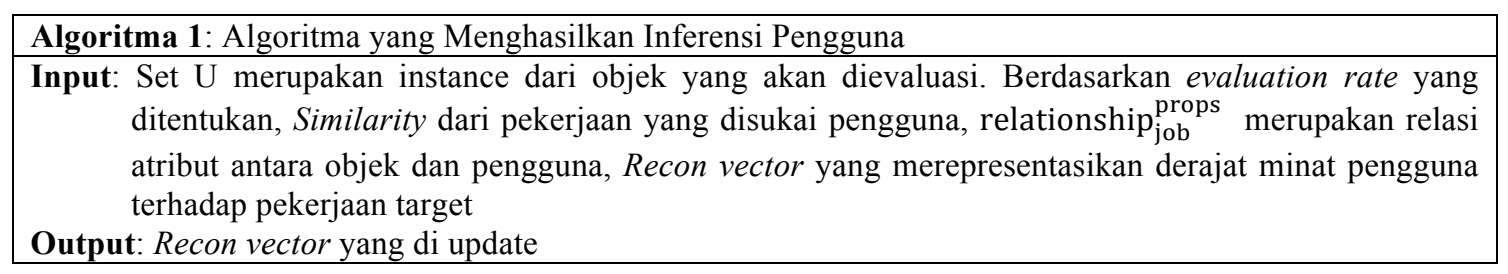


SARI RAHMAWATI ET.AL.

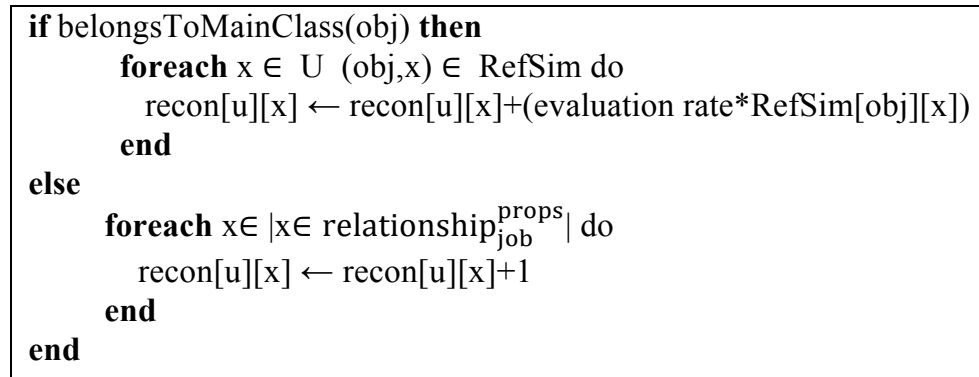

Setelah didapatkan hasil recon vector pada tiap pengguna maka akan dicari hasil prediksi dengan persamaan 4 [4].

$$
\mathrm{U}_{\mathrm{x}}^{\prime}=\left(\frac{\operatorname{recon}[\mathrm{u}][\mathrm{x}]}{\operatorname{maxrecon}[\mathrm{u}][\mathrm{x}]}\right) * \max \text { Interaksi }
$$

Keterangan :

- $\quad \operatorname{recon}[\mathrm{u}][\mathrm{x}]$ adalah derajat minat berdasarkan fitur dari pengguna $\mathrm{u}$ terhadap pekerjaan $\mathrm{x}$

- $\quad \operatorname{maxrecon}[\mathrm{u}][\mathrm{x}]$ nilai derajat minat maksimum yang bisa didapatkan oleh pengguna $\mathrm{u}$

- maxInteraksi adalah interaksi maksimum pengguna terhadap pekerjaan, dalam kasus ini interaksi maksimumnya adalah 3

\section{Hybrid Recommender System}

Hybrid recommender system adalah suatu teknik yang menggabukan beberapa teknik rekomendasi. Hybrid recommender system memiliki teknik hybrid seperti yang dijelaskan pada Tabel 1 [4].

Tabel 1. Teknik Hybrid

\begin{tabular}{|l|l|}
\hline \multicolumn{1}{|c|}{ Teknik Hybrid } & \multicolumn{1}{c|}{ Deskripsi } \\
\hline Weighted & $\begin{array}{l}\text { Nilai Pada rekomendasi antara beberapa teknik di gabungkan berdasarkan parameter } \\
\text { tertentu }\end{array}$ \\
\hline Switching & Sistem menggabungkan 2 buah teknik secara bergantian \\
\hline Mixed & Rekomendasi dari beberapa recommender disatukan \\
\hline Cascade & Suatu rekomendasi memperbaik hasil dari rekomendasi lain \\
\hline Feature Augmentation & Output dari suatu teknik digunakan untuk input dari teknik lainya \\
\hline Meta-level & $\begin{array}{l}\text { Model yang dipelajari dari suatu recommender digunakan untuk input pada } \\
\text { recommender lain }\end{array}$ \\
\hline
\end{tabular}

Pada penelitian ini penulis menggunakan metode hybrid dengan teknik weighted berdasarkan social aperture yang diberikan. Social aperture pada kasus ini adalah nilai rekomendasi pada orang-orang berdasarkan pada preferensi pribadi dan kesamaan pengguna terhadap pengguna lainya. Social aperture dibagi menjadi 2 yaitu moderate dan liberal. Social aperture moderate artinya pengguna lebih cenderung memilih rekomendasi sebanyak $75 \%$ berdasarkan preferensi pribadinya, $25 \%$ berdasarkan hasil rekomendasi dari pengguna lain. Sedangkan social aperture liberal menggabungkan hasil rekomendasi dengan nilai yang seimbang yaitu $50 \%$ berdasarkan preferensi pribadi dan $50 \%$ berdasarkan pada rekomendasi dari pengguna lain [3]. 


\section{PERANCANGAN SISTEM}

\section{A. Dataset}

Penelitian in menggunakan dataset dari Xing yang didapatkan dari Recsys Challenge 2016 [11]. Dataset tersebut memiliki karakteristik seperti pada Tabel 2.

Tabel 2. Karakteristik Dataset

\begin{tabular}{|c|c|c|c|l|}
\hline Pengguna & Pekerjaan & Data Interaksi & Density & \multicolumn{1}{c|}{ Keterangan } \\
\hline 1.500 .001 & 1.358 .099 & 2114575 & $1.03 \%$ & $\begin{array}{l}\text { Terdapat 1\% data yang memiliki jumlah } \\
\text { interaksi lebih dari 0 }\end{array}$ \\
\hline
\end{tabular}

\section{B. Ontologi Sistem}

Untuk memodelkan domain knowledge pada knowledge based recommender system maka dibutuhkan ontologi. Ontologi adalah model formal dari suatu struktur sistem yang dapat dimengerti manusia dan dibaca mesin. Ontologi terdiri dari atribut, relasi, entitas dan axiom. Ontologi dapat menyediakan konseptualisasi yang beraneka ragam untuk menggambarkan domain pekerjaan dari suatu organisasi yang merepresentasikan konsep dan relasi dari aktivitas kerja. Dataset yang digunakan pada penelitian ini digambarkan dengan ontologi seperti pada Gambar 1.

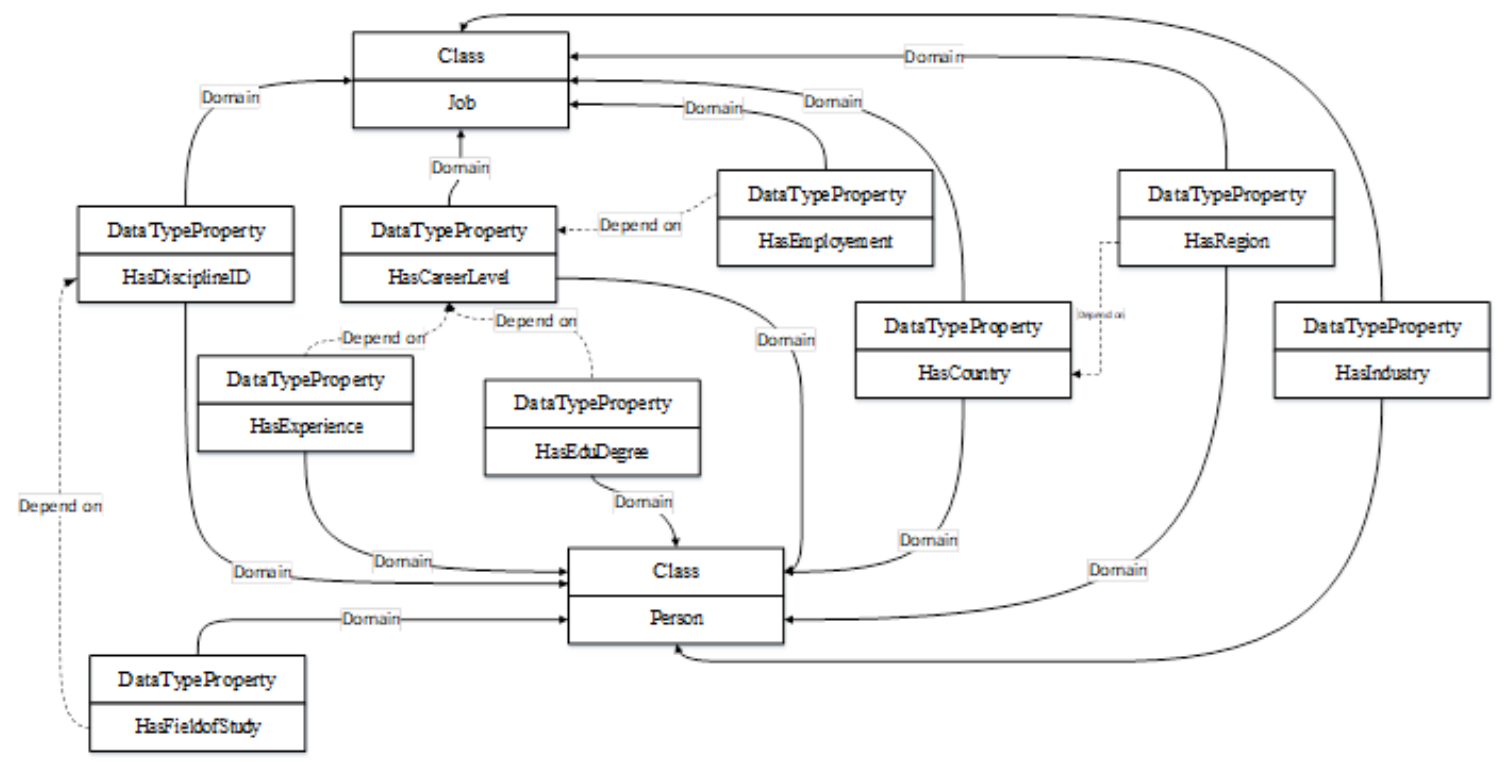

Gambar 1. Ontologi Sistem

\section{Gambaran Umum Sistem}

Secara umum, rancangan recommender system yang dibangun pada penelitian ini adalah seperti pada Gambar 2.

\section{Perancangan Knowledge Based Recommender System}

Gambar 3 merupakan rancangan dari knowledge based recommender system yang dibangun pada penelitian ini. 
Sari Rahmawati ET.AL.

Analisis dan Implementasi Pendekatan...

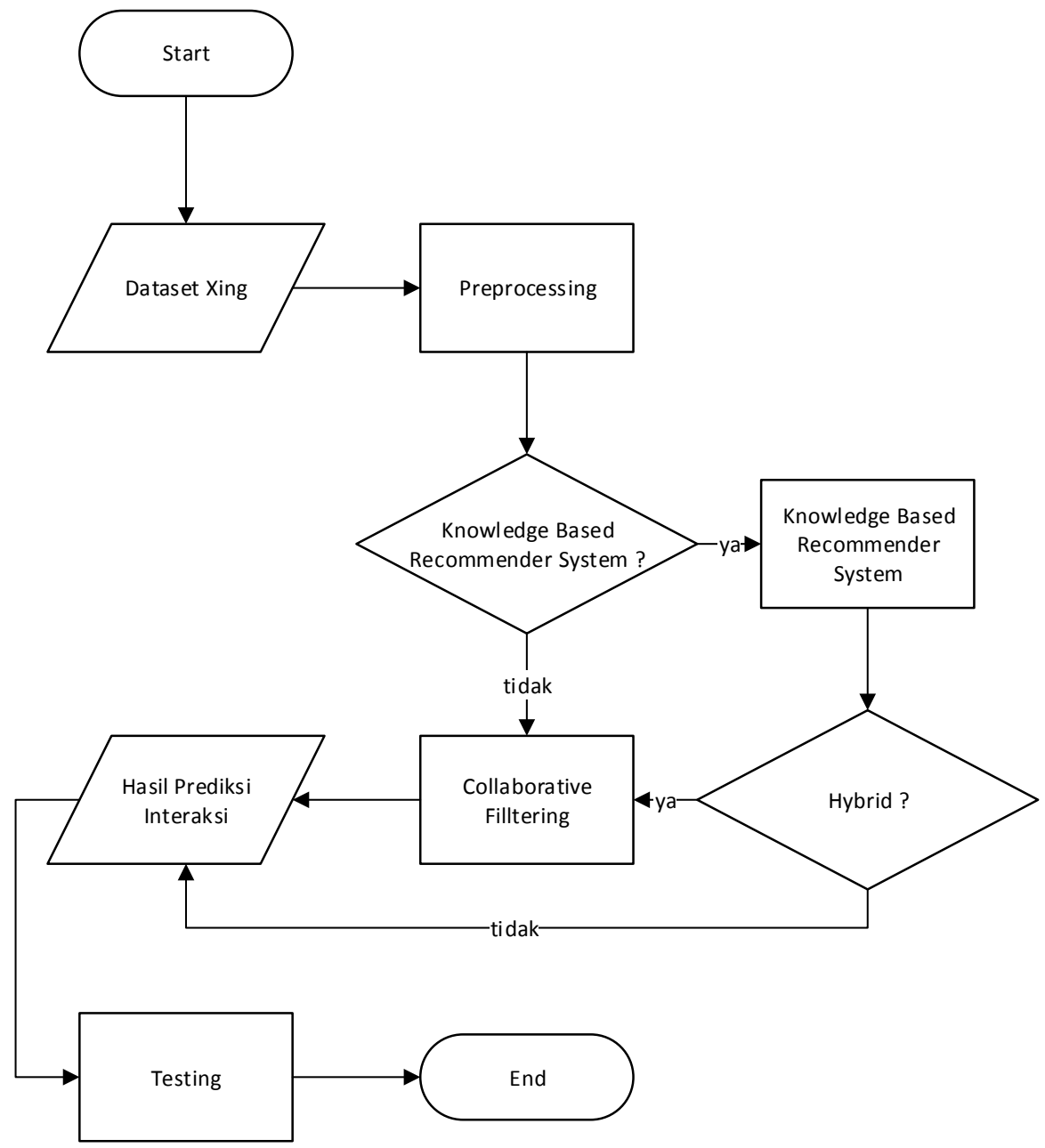

Gambar 2. Gambaran Umum Sistem

\section{E. Perancangan Collaborative Filtering}

Gambar 4 merupakan rancangan dari collaborative filtering yang dibangun pada penelitian ini.

\section{F. Perancangan Collaborative Filtering}

Metode hybrid yang digunakan pada rekomendasi ini adalah weighted dimana hasil prediksi dari knowledge based akan digabungkan dengan collaborative filtering dengan bobot tertentu berdasarkan pengaruh dari masing masing social aperture. Social aperture moderate mengkonfigurasi profil sistem untuk menimbang rekomendasi berdasarkan knowledge based recomender system dengan bobot 0,75 dan bobot rekomendasi berdasarkan collaborative filtering adalah 0,25. Pada social aperture liberal mengarah pada penerapan bobot 0,5 pada kedua masing masing metode. 


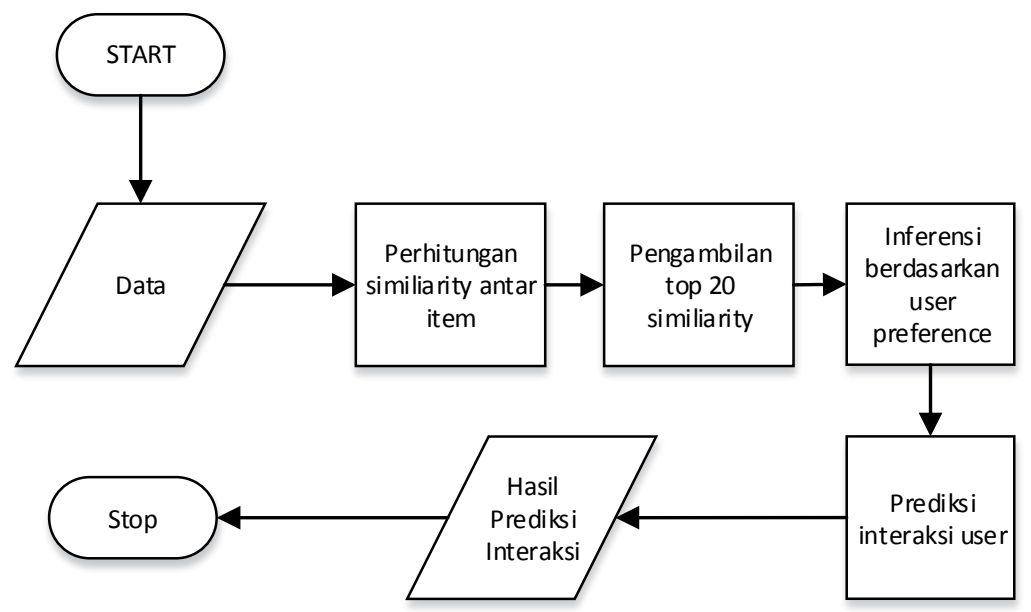

Gambar 3. Proses Knowledge Based Recommender System

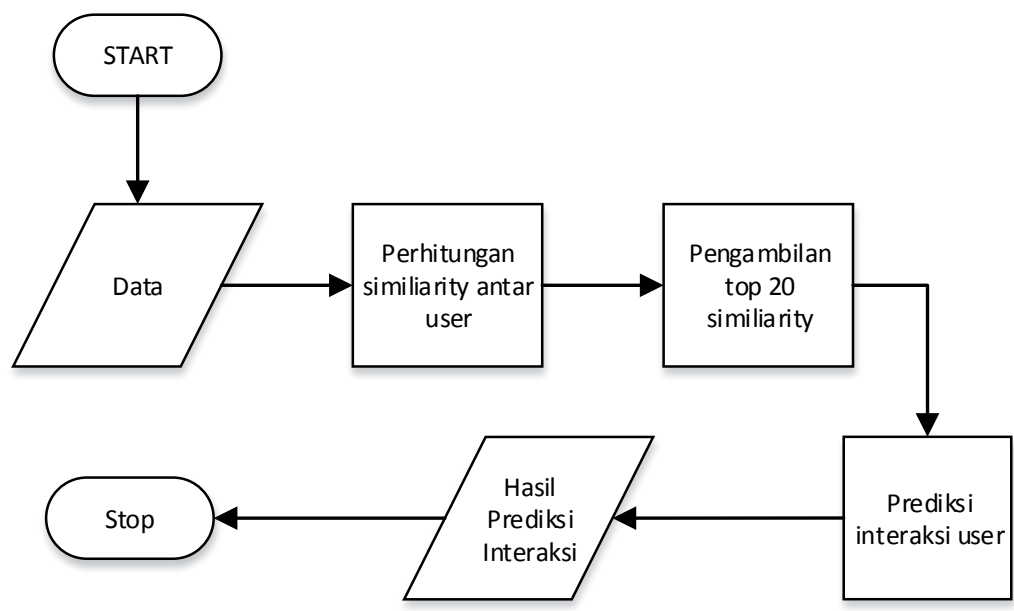

Gambar 4. Proses Collaborative Filtering

\section{RESUlts AND DiscUSSION}

\section{A. Skenario Pengujian Prediksi Interaksi}

Evaluasi ini bertujuan untuk mengetahui pengaruh hybrid recommender system untuk memprediksi interaksi yang dilakukan pengguna terhadap pekerjaan. Hasil prediksi interaksi diukur nilai errornya dengan menggunakan RMSE pada persamaan 5 [2]. Semakin kecil nilai error pada RMSE maka semakin baik sistem yang dibuat.

$$
R M S E=\sqrt{\frac{1}{n} \sum_{i=1}^{n}\left(y_{i}-\hat{y}_{i}\right)^{2}}
$$

dimana $\hat{y}_{i}$ merupakan nilai yang diamati untuk observasi (nilai aktual) ke i dan $y_{i}$ adalah nilai prediksi. 
SARI RAHMAWATI ET.AL.

Analisis DAN Implementasi Pendekatan...

Pengukuran RMSE pada sistem rekomendasi dilakukan dengan $\mathrm{k}$ fold cross validation dengan nilai $\mathrm{k}$ adalah 10 menggunakan 41381 data training pada setiap iterasi dari jumlah data testing sebanyak 4034 data interaksi pada setiap iterasi. Iterasi akan dilakukan sebanyak 10 kali contohnya pada iterasi pertama akan diambil $10 \%$ data interaksi pertama yang di interaksi pengguna antara pengguna dan pekerjaan lalu $90 \%$ data interaksi akan menjadi data training. Untuk membandingkan hasil rekomendasi, nilai RMSE akan dihitung dengan metode knowledge based system, collaborative filtering dan rekomendasi hybrid.

\section{B. Skenario Pengujian Rekomendasi Top N}

Evaluasi ini betujuan untuk mengetahui hasil F1 score pada recommender system dalam merekomendasikan pekerjaan. Pengujian ini akan menggunakan Top $\mathrm{N}$ recommendation dengan nilai $\mathrm{N}$ adalah 1, 3, 5, 15, $25,50$. Sistem akan merekomendasikan pekerjaan pekerjaan dengan $\mathrm{N}$ ranking teratas. Evaluasi hasil rekomendasi menggunakan F1 measure dengan menggunakan persamaan 8 [4].

$$
\begin{gathered}
\text { precision }=\frac{\mid \text { Rekomendasi pekerjaan yang relevan } \mid}{\mid \text { Seluruh pekerjaan yang direkomendasikan } \mid} \\
\text { recall }=\frac{\mid \text { Rekomendasi pekerjaan yang relevan } \mid}{\mid \text { Seluruh pekerjaan yang relevan } \mid} \\
\text { F1 }- \text { Measure }=\frac{2 * \text { Precision } * \text { Recall }}{\text { Precision }+ \text { Recall }}
\end{gathered}
$$

Pada evaluasi rekomendasi ini, hasil rekomendasi pekerjaan dibagi menjadi dua yaitu relevant dan irrelevant. Pekerjaan relevant adalah pekerjaan dengan nilai interaksi 1,2,3, sedangkan pekerjaan irrelevant adalah pekerjaan dengan nilai interaksi 0. [4] Pengujian ini dilakukan dua percobaan, pada percobaan pertama jumlah interaksi minumum tiap pengguna adalah 15. Setelah itu dilakukan percobaan kedua dengan jumlah interaksi minimum tiap pengguna adalah 20. Pada data testing akan dihilangkan 5 rekomendasi pada setiap pengguna secara random. Dua percobaan ini bertujuan untuk mengetahui dampak perubahan data uji dan dan nilai n pada Top $\mathrm{N}$ recommendation untuk masing masing metode.

\section{Hasil Pengujian Prediksi Interaksi}

\begin{tabular}{|c|c|c|c|c|}
\hline & \multicolumn{3}{|c|}{ RMSE } \\
\hline & & Rata-Rata & Minimum & Maksimum \\
\hline \multirow{4}{*}{$\begin{array}{l}\frac{0}{0} \\
\frac{0}{0} \\
\sum\end{array}$} & Knowledge Based System (KBS) & 0.357 & 0.287 & 0.457 \\
\hline & Collaborative Filtering (CF) & 0.526 & 0.475 & 0.617 \\
\hline & Hybrid Liberal & 0.449 & 0.398 & 0.532 \\
\hline & Hybrid Moderate & 0.347 & 0.283 & 0.433 \\
\hline
\end{tabular}

Tabel 3 adalah RMSE yang dihasilkan dari keempat metode yang diujikan.

Tabel 3. RMSE Prediksi Interaksi

Hasil pengujian pada Tabel 3 menunjukan bahwa pada prediksi interaksi pengguna terhadap pekerjaan dengan menggunakan $k$-fold cross validation, CF yang berbasis kesamaan preferensi antar pengguna, memiliki hasil yang lebih buruk dibandingkan metode-metode lain dengan nilai rata-rata RMSE paling besar yaitu 0.526. Hal ini dikarenakan dalam memprediksi interaksi, CF hanya mempertimbangkan kesamaan pengguna terhadap pengguna lainya tanpa mempertimbangkan preferensi pribadi pengguna sehingga saat terjadi sparsity pada data, hasil rekomendasi CF menjadi tidak optimal. Selain itu hal ini juga menunjukkan bahwa untuk memprediksi interaksi pengguna terhadap pekerjaan yang ditawarkan, preferensi pribadi lebih berpengaruh dibanding kesamaan preferensi antar pengguna. Dapat terlihat dari metode-metode lain yang melibatkan KBS 
yang berbasis preferensi pribadi pengguna, hasilnya lebih baik daripada CF. Terutama pada metode hybrid moderate yang mana bobot KBS lebih besar daripadaCF, dihasilkan RMSE terkecil yaitu 0.347.

\section{Hasil Pengujian Rekomendasi Top $N$}

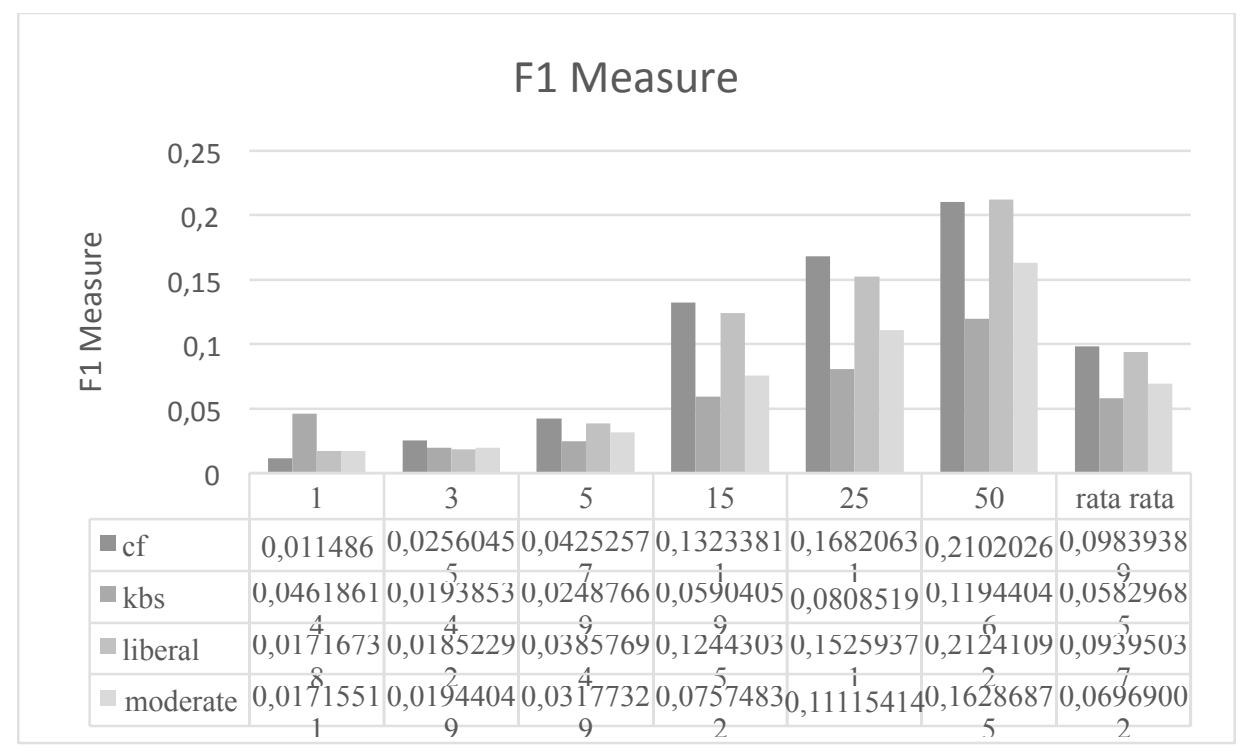

Gambar 5. Hasil F1 Score Pengujian Rekomendasi Top N dengan Minimum Interaksi $=15$

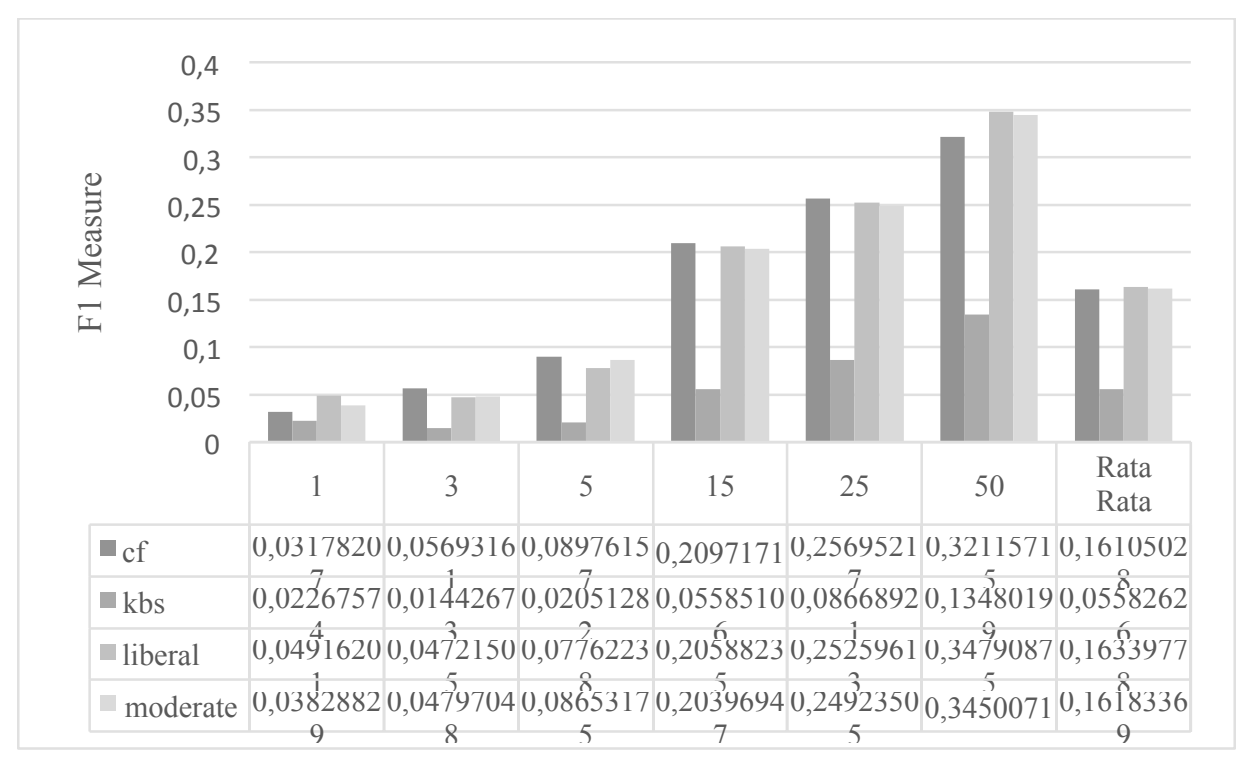

Gambar 6. Hasil F1 Score Pengujian Rekomendasi Top N dengan Minimum Interaksi $=20$

Secara umum, F1 score untuk data dengan interaksi minimum 20 lebih baik dibanding data dengan interaksi minimum 15. Hal ini dikarenakan dengan semakin banyaknya interaksi yang dilakukan oleh pengguna berarti data semakin padat sehingga semakin banyak informasi yang digunakan untuk menentukan kemiripan antar pengguna. Untuk pengujian rekomendasi Top N, metode-metode yang melibatkan CF memiliki hasil yang lebih baik dibandingkan metode tanpa CF karena CF merekomendasikan pekerjaan berdasarkan kesamaan antar pengguna, sehingga mengakibatkan pekerjaan-pekerjaan yang direkomendasikan adalah pekerjaan 
SARi RAhMAWATi ET.AL.

Analisis dan Implementasi Pendekatan...

populer yang kemungkinan besar relevan dengan yang dicari oleh pengguna. F1 score terbaik didapatkan dengan menggunakan metode hybrid dengan social aperture liberal yaitu 0.347. Sedangkan metode hybrid dengan social aperture moderate mendapatkan F1 score terbaik 0,345. Hasil F1 score pada rekomendasi masih belum maksimal dikarenakan pada data testing banyak pekerjaan yang seharusnya direkomedasikan memiliki ranking lebih dari $\mathrm{n}$. Hal ini disebabkan banyaknya informasi pengguna yang kosong sehingga mempengaruhi proses inferensi pengguna. Selain itu pada dataset yang digunakan juga memiliki beberapa kelemahan yaitu dataset mengandung pengguna buatan dan tidak semua interaksi dari pengguna merupakan interaksi sebenarnya atau interaksi yang terdapat pada dataset merupakan data artificial. [13]

Pada gambar 5 dan 6 dapat dilihat bahwa hasil recommender system pada CF dan KBS dapat naik turun secara signifikan tergantung nilai n pada Top N recommendation. Sedangkan hasil dari rekomendasi hybrid justru cenderung selalu naik jika nilai $\mathrm{n}$ bertambah pada tiap nilai $\mathrm{n}$. Artinya untuk mendapatkan hasil rekomendasi yang baik, tidak cukup hanya menggunakan CF saja atau KBS saja, tetapi perlu untuk menggabungkan kedua metode tersebut sehingga didapatkan hasil yang lebih optimal.

\section{KESIMPULAN}

Dari penelitian ini dapat disimpulkan bahwa untuk mendapatkan hasil rekomendasi yang baik, tidak cukup hanya menggunakan collaborative filtering saja atau knowledge based saja, tetapi perlu untuk menggabungkan kedua metode tersebut (hybrid) sehingga didapatkan hasil yang lebih optimal. Sistem rekomendasi dengan menggunakan metode hybrid memberikan hasil prediksi dan rekomendasi yang lebih baik dibandingkan dengan system rekomendasi yang menggunakan metode collaborative filtering saja atau knowledge based saja. Dimana metode rekomendasi hybrid dengan social aperture moderate mendapatkan hasil paling baik untuk prediksi interaksi dengan nilai rata-rata RMSE paling kecil yaitu 0.347. Sedangkan pada rekomendasi Top N, F1 score terbaik didapatkan dengan menggunakan metode hybrid dengan social aperture liberal yaitu 0.347 dengan nilai $\mathrm{n}=50$.

\section{REFERENCES}

[1] F. Rici, L. Rokach, S. Bracha and K. B. Paul, Recommender System Handbook, New York: Springer, 2011.

[2] h. w. y. f. n. zheng siting, "Job recommender systems: A survey," in Computer Science \& Education (ICCSE), 20127 th International Conference on, 2012.

[3] S. Z. H. W. Wexing Hong, "A Job Recommender System Based on User," JOURNAL OF COMPUTERS, vol. 8, no. 8, p. 1960, 2013.

[4] W. C. Neto, L. M. Hernandez-Alcaraz, R. V. Garcia and S. G. Fransisco, "Social Knowledge Based Recommender System. Application to the movies domain," vol. 39, 2012.

[5] R. Burke, "Knowledge-based recommender systems," Encyclopedia of Library and Information Science.

[6] b. j, o. f, h. a and g. a, "Recommender systems survey," Knowledge-based system, p. 24, 2013.

[7] D. D. R. Stuart E. Middleton and N. R. Shadbolt, "Ontology-Based Recommender Systems," in Handbooks on onthologies.

[8] "Kaggle - Root Mean Squared Error (RMSE)," 18 Januari 2016. [Online]. Available: https://www.kaggle.com/wiki/RootMeanSquaredError. [Accessed 28 Maret 2016].

[9] L. Smith, "What is My "Career Level"?," 2015. [Online]. Available: http://www.thelettersmith.com/Levels.htm. [Accessed 2017].

[10] J. K. ,. J. R. J. Ben Schafer, "Recommender System in E-commerce," ACM, 1999.

[11] "2016 Recsys Challenge," 2016. [Online]. Available: http://2016.recsyschallenge.com/. [Accessed Januari 2017].

[12] J. Schneider, "Cross Validation," 7 Februari 1997. [Online]. Available: https://www.cs.cmu.edu/ schneide/tut5/node42.html.

[13] A. Dekhtyar, "Collaborative Filtering and Recommender Systems," 2009.

[14] R. Burke, "Hybrid Recommender Systems:Surveys and experiments". 